\title{
New and revised occurrences of Dihoplus megarhinus (Mammalia, Rhinocerotidae) in the Pliocene of Italy
}

\author{
Luca Pandolfi
}

Received: 23 January 2013/Accepted: 21 May 2013/Published online: 14 November 2013

(C) Akademie der Naturwissenschaften Schweiz (SCNAT) 2013

\begin{abstract}
Several rhinoceros remains, collected in the Pliocene deposits of Northern Italy and usually ascribed to Dicerorhinus or Rhinoceros megarhinus, are revised; furthermore, unpublished Pliocene remains are also described. The material is compared with the respective anatomical elements of Dihoplus megarhinus, Stephanorhinus jeanvireti and Stephanorhinus etruscus. Based on morphological and morphometrical comparisons, the presence of Dihoplus megarhinus is confirmed in at least ten sites. In other Late Pliocene fossiliferous localities, the presence of $S$. jeanvireti and/or S. etruscus is recorded. D. megarhinus occurred in Italy at the beginning of the Early Pliocene. It was well represented in Val di Pugna (Tuscany) and in several Pliocene marine deposits near Bologna by fragmentary mandibles, some postcranial remains and few teeth. The species disappeared before the beginning of the Villafranchian (Late Pliocene) when S. jeanvireti and S. etruscus cooccurred both in the site of Villafranca d'Asti and Montopoli. S. jeanvireti disappeared in Italy at the Pliocene-Early Pleistocene transition whereas $S$. etruscus was widespread in Central and Southern Italy.
\end{abstract}

Keywords Rhinocerotidae - Dihoplus - Stephanorhinus . Pliocene $\cdot$ Italy

\section{Introduction}

The taxonomy of the European Plio-Pleistocene rhinoceroses is still debated. Guérin (1980, 1982, 2004) assigned

L. Pandolfi $(\bowtie)$

Section of Geology, Department of Science, University of Roma

TRE, Largo S. L. Murialdo 1, 00146 Rome, Italy

e-mail: luca.pandolfi@uniroma3.it them, with the exception of the species of the genera Coelodonta and Elasmotherium, to the genus Dicerorhinus (abbrev. Di.) and the species Di. megarhinus to the subgenus Dicerorhinus, the species Di. miguelcrusafonti to an indeterminate subgenus and the other species to the subgenus Brandtorhinus. Genus Stephanorhinus was ascribed by Fortelius et al. (1993) to the species $S$. megarhinus, $S$. jeanvireti, $S$. etruscus, $S$. hundsheimensis (partially identified to Dicerorhinus etruscus brachycephalus in Guérin 1980), S. hemitoechus and S. kirchbergensis (=Dicerorhinus mercki in Guérin 1980). Later, Cerdeño (1995) included the species $S$. miguelcrusafonti in this genus. Moreover, Heissig (1999) supposed a long European lineage from the Miocene Dihoplus schleiermacheri to the Pliocene D. megarhinus which was included in this genus also by Lacombat and Mörs (2008). Recently, Deng et al. (2011) ascribed the species D. megarhinus to the genus Dihoplus, together with the Miocene species D. ringstroemi and D. pikermiensis; however, D. schleiermacheri, the type species of the genus, was not included in their analysis.

During the Pliocene, four species of rhinoceros were present in Europe: D. megarhinus, "S." miguelcrusafonti, $S$. jeanvireti and S. etruscus.

D. megarhinus was named by De Christol (1834) and it is recorded from several Pliocene sites of Western Europe (Spain, France, Italy, Belgium and Germany), in Romania, Poland and Turkey (Guérin 1980; Guérin and Sen 1998). Recently, it was also reported in the Late Pliocene site of Udunga (Transbaikalia, Russia) (Fukuchi et al. 2009). "S." miguelcrusafonti has a very restricted geographic and chronological distribution and it was recovered in few Spanish sites and in one French site (Guérin 1980; Cerdeño 1989). The latter species was described by Guérin and Santafé-Llopis (1978) based on few teeth, a fragmentary 
mandible and several postcranial remains. Unfortunately, skulls and complete mandibles are still unknown and the systematic position of the species appears problematic. Morphologically, the species appears to be close to $D$. megarhinus and the differences between them are minor. $S$. jeanvireti was a slender, medium-large-sized rhino with brachydont teeth (Guérin 1972, 1980). It is the oldest true species of the genus Stephanorhinus and it was present in Europe during the Late Pliocene. During this time, it cooccurs with the small S. etruscus (Guérin 1980; Lacombat and Mörs 2008). The morphological and morphometrical differences between D. megarhinus and $S$. jeanvireti are obvious in the skull but less in postcranial remains. On the contrary, D. megarhinus appears to be easily distinguishable from S. etruscus.

The aim of this paper is to provide a comprehensive updated overview of the knowledge of Dihoplus megarhinus in Italy with a revision of the Pliocene records and their palaeobiogeographic and biochronological implications.

\section{Materials and methods}

The revised Quaternary time scale (Gibbard et al. 2010) for chronological references is used in this text; the Pliocene then spans approximately the period between 5.4 and 2.6 Ma.

This work is based on the fossil material stored in the following Institutions: Natural History Museum, Section of Geology and Paleontology, Florence (Florence) (MGPF), Museum of Geology G. Capellini (Bologna) (MGC), Natural History Museum Basel (Basel) (NMB), Natural History Museum, Fisiocritici Academy, Siena (Siena) (MSNAF) and Paleontological Museum, Sapienza University of Rome (Rome) (MPUR). The rhinoceros remains consist of isolated teeth, mandibles, a pelvis and several limb bones; a list of the revised remains is reported in Table 1. The majority of the studied specimens were described and partially figured by Cuvier (1822), De Christol (1834), Falconer (1868), Capellini (1894, 1913), Simonelli (1897, 1919), Sacco (1906), Cuscani Politi (1963a, b, 1973, 1977) and Azzaroli (1962). Guérin (1980) included part of this material in his work and listed the fossiliferous Pliocene localities in which rhinoceros remains have been recovered. However, the specific attribution given by Guérin (1980) was not fully accepted in the literature (e.g. Fortelius et al. 1993; Bianucci et al. 2001).

The Pliocene sites in which the studied specimens have been recovered are located in Northern Italy (Northern Tuscany, near Bologna and Piacenza and in Piedmont) (Fig. 1). The remains have been usually found in marine deposits chronologically referred to the Early Pliocene (e.g.
Val di Pugna, referred to the European Neogene Mammal Fauna Zone 14; Bianucci et al. 2001) or in continental deposits chronologically related to the Late Pliocene/earliest Early Pleistocene (MN 15 and 16) (e.g. Montopoli, Barga Basin, Monte Tiffi) (Azzaroli 1973; Kotsakis 1986; Coltorti et al. 2008). Unfortunately, the fossiliferous levels in which several rhino remains have been collected are unknown or have an uncertain chronostratigraphic position. However, the Pliocene localities in which remains have been discovered are generally referred to the Early or early Late Pliocene (Ruscinian Mammal Age, MN14-15) (e.g. Montelungo, Colle della Casazza and other) (Kotsakis 1986 and references therein; Kotsakis et al. 1997).

For the morphological comparison of the fossil specimens, different remains from Pliocene and Early Pleistocene European sites are taken into account. In particular, the material of $D$. megarhinus from Montpellier and Lens-Lestang stored at NMB, of $S$. jeanvireti from Vialette and Villafranca d'Asti stored at NMB and of $S$. etruscus from St. Vallier stored at NMB, from the Upper Valdarno stored at NMB and MGPF and from Capitone stored at MPUR have been considered. Furthermore, figures and descriptions reported by several authors are taken into account (in particular: De Christol 1834; Falconer 1868; Sacco 1895, 1906; Simonelli 1897; Guérin et al. 1969; Guérin and Santafé-Llopis 1978; Guérin 1972, 1980).

The morphometric methodology is based on the work of Guérin (1980), Fortelius et al. (1993) and Lacombat (2005). Ratio diagrams are made using data on extant Diceros bicornis (data from Guérin 1980) as a reference.

\section{Systematic palaeontology}

Order Perissodactyla OWEN, 1848

Family Rhinocerotidae GRAY, 1821

Genus Dihoplus Brandt, 1878

Type species Rhinoceros schleiermacheri Kaup, 1832 from Eppelsheim, Late Miocene.

Other species Dihoplus megarhinus (De Christol 1834), Dihoplus pikermiensis (Toula 1906), Dihoplus ringstroemi (Arambourg 1959).

Diagnosis (description from Brandt 1878; Geraads and Spassov 2009) Two-horned rhino. Occipital crest relatively high and large. Nasal bones relatively wide and thick. Posterior end of the nasal notch short and rounded. Post-glenoid apophysis close to the post-tympanic one. First upper premolar absent. Presence of second lower incisors.

Species Dihoplus megarhinus (De Christol 1834) 
Table 1 Revised list of rhinoceros specimens from the Pliocene of Italy

\begin{tabular}{|c|c|c|c|c|c|}
\hline Institution & Specimen or reference & Anatomical element & Site & Age & Taxonomy \\
\hline MSNAF & MSNAF4743 & Fragmentary mandible & $\begin{array}{l}\text { Val di Pugna, } \\
\text { Fangonero-Bucca }\end{array}$ & Early Pliocene & D. megarhinus \\
\hline MSNAF & MSNAF4747 & Fragmentary mandible & $\begin{array}{l}\text { Val di Pugna, } \\
\text { Fangonero-Bucca }\end{array}$ & Early Pliocene & D. megarhinus \\
\hline MSNAF & MSNAF4555 & Fragmentary upper molar & $\begin{array}{l}\text { Val di Pugna, } \\
\text { Fangonero-Bucca }\end{array}$ & Early Pliocene & cf. D. megarhinus \\
\hline MSNAF & MSNAF7100 & Fragmentary humerus & $\begin{array}{l}\text { Val di Pugna, } \\
\text { Fangonero-Bucca }\end{array}$ & Early Pliocene & D. megarhinus \\
\hline MSNAF & MSNAF7101 & Fragmentary humerus & $\begin{array}{l}\text { Val di Pugna, } \\
\text { Fangonero-Bucca }\end{array}$ & Early Pliocene & D. megarhinus \\
\hline MSNAF & MSNAF4754 & Fragmentary radius & $\begin{array}{l}\text { Val di Pugna, } \\
\text { Fangonero-Bucca }\end{array}$ & Early Pliocene & cf. D. megarhinus \\
\hline MGPF & IGF5957v & Fragmantary mandible & Pliocene of Siena & Early Pliocene & D. megarhinus \\
\hline MSNAF & MSNAF4531 & Calcaneum & Senese & Early Pliocene & D. megarhinus \\
\hline MSNAF & MSNAF4761 & $\begin{array}{l}\text { Second and third lower } \\
\text { premolars }\end{array}$ & $\begin{array}{l}\text { Val di Pugna- } \\
\text { Montarioso }\end{array}$ & Early Pliocene & D. megarhinus \\
\hline MSNAF & MSNAF7000 & First upper molar & $\begin{array}{l}\text { Val di Pugna- } \\
\text { Montarioso }\end{array}$ & Early Pliocene & D. megarhinus \\
\hline MSNAF & MSNAF7100 & First upper molar & $\begin{array}{l}\text { Val di Pugna- } \\
\text { Montarioso }\end{array}$ & Early Pliocene & D. megarhinus \\
\hline MGC & MGC1870 & Fragmentary humerus & Colle della Casazza & Early Pliocene & D. megarhinus \\
\hline MGPT & $\begin{array}{l}\text { Sacco 1906, Tav. I figs. } 1 \\
\text { and } 2\end{array}$ & $\begin{array}{l}\text { First and second molars and } \\
\text { fourth premolar }\end{array}$ & $\begin{array}{l}\text { Dusino-San Paolo, } \\
\text { lower levels }\end{array}$ & Early Pliocene & D. megarhinus \\
\hline MGC & MGC sn (cast) & Upper molar & Montelungo & Early Pliocene & D. megarhinus \\
\hline MPPB & MPPB sn & Fragmentary mandible & Monte Biancano & Early Pliocene & D. megarhinus \\
\hline MPP & $\begin{array}{l}\text { Simonelli 1898, pp 91- } \\
\text { 112,Tav. X, XI, XII, XII }\end{array}$ & $\begin{array}{l}\text { Several bones, teeth and a } \\
\text { fragmentary mandible }\end{array}$ & Monte Giogo & Early Pliocene & D. megarhinus \\
\hline \multirow[t]{2}{*}{$\begin{array}{l}\text { MGC and } \\
\text { MGPF }\end{array}$} & $\begin{array}{l}\text { MGC9352, IGF4684 } \\
\text { (cast) }\end{array}$ & Fragmentary mandible & Monte Pulgnasco & Pliocene & S. jeanvireti \\
\hline & $\begin{array}{l}\text { Cuvier } 1823, \text { Pl. } 47 \text {, } \\
\text { fig. } 7 \text {; Falconer } 1868 \text {, } \\
\text { pp } 381-390\end{array}$ & Skull and mandible & Montezago & Early Pliocene & D. megarhinus \\
\hline MGPF & IGF5566v & Nasal bone & Palaia & Early Pliocene & D. megarhinus \\
\hline MGPF & IGF13091 & Fragmentary mandible & Palaia & Early Pliocene & D. megarhinus \\
\hline MGC & MGC sn & Astragalus & Pradalbino & Pliocene & S. jeanvireti \\
\hline MGC & MGC9350 & Fragmentary pelvis & Rio Secco & Early Pliocene & D. megarhinus \\
\hline MSNP & $\begin{array}{l}\text { Azzaroli 1962, Tav. VII } \\
\text { fig. 3, tav. XI fig. } 5\end{array}$ & Fragmentary mandible & S. Regolo & Pliocene & cf. D. megarhinus \\
\hline MGC & MGC7584 & Lower molar & Barga Basin & Late Pliocene & Rhinocerotini indet. \\
\hline MSNP & Ugolini 1918, Tav. XIII & Maxillae & Barga Basin & Late Pliocene & S. etruscus \\
\hline MGC & MGC sn & Fragmentary nasal bones & Costa Marenga & Late Pliocene & S. etruscus \\
\hline MGPF & IGF1450v & Fragmentary mandible & $\begin{array}{l}\text { Lucardo (near } \\
\text { Montopoli) }\end{array}$ & Late Pliocene & Stephanorhinus sp. \\
\hline MGC & MGC sn & $\begin{array}{l}\text { Proximal and distal } \\
\text { epiphysis of humerus }\end{array}$ & Monte Pastore & Late Pliocene & S. jeanvireti \\
\hline MGC & MGC9354 & Mandible & Monte San Pietro & Late Pliocene & S. jeanvireti \\
\hline MGPF & IGF1452v & Astragalus & Montopoli & Late Pliocene & S. etruscus \\
\hline MGPF & IGF4688v & Fragmentary metatarsus & Montopoli & Late Pliocene & S. cf. etruscus \\
\hline MGPF & IGF1075 & $\begin{array}{l}\text { Lower check teeth and four } \\
\text { limbs. }\end{array}$ & Montopoli & Late Pliocene & S. jeanvireti \\
\hline MGPF & IGF14869 & Fragmentary skull & Montopoli & Late Pliocene & S. jeanvireti \\
\hline MGPF & IGF1449v & Fragmentary mandible & Capannoli & Late Pliocene & S. jeanvireti \\
\hline
\end{tabular}


Table 1 continued

\begin{tabular}{llllll}
\hline Institution & Specimen or reference & Anatomical element & Site & Age & Taxonomy \\
\hline MGC & MGC sn & Fragmentary astragalus & Monte Tiffi & Late Pliocene & Stephanorhinus sp. \\
MGC & MGC sn & Fourth lower premolar & Sarzanello & Late Pliocene & Rhinocerotini indet.
\end{tabular}

$M S N A F$, Natural History Museum, Fisiocritici Academy, Siena; MGPF Natural History Museum, section of Geology and Paleontology, Florence; MGC Museum of Geology G. Capellini, Bologna; MPPB Museum of Palazzo Poggi, Bologna; MPP Paleontological Museum, University of Parma; MSNP Natural History Museum, University of Pisa; MGPT Museum of Geology and Paleontology, University of Turin

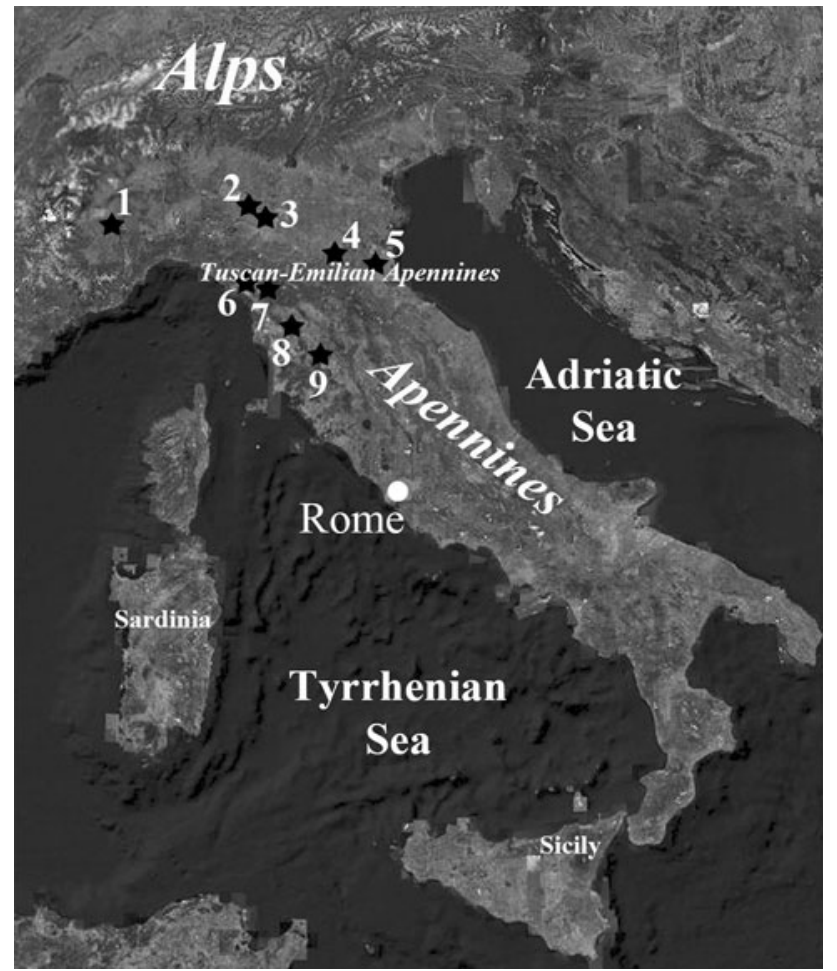

Fig. 1 Location of the Pliocene fossiliferous localities cited in the text: Dusino-San Paolo and Villafranca d'Asti (1); Montezago, Monte Giogo and Monte Pulgnasco (2); Costa Marenga (3); Colle della Casazza, Monte Biancano, Montelungo, Monte Pastore, Rio Secco, Pradalbino and Monte San Pietro (4); Monte Tiffi (5); Sarzanello (6); Barga Basin (7); Lower Valdarno (various localities including Montopoli, Palaia, Lucardo, S. Regolo and Capannoli) (8); Val di Pugna (9)

Synonymy list 1820 Rhinoceros cuvieri, Desmarest, 402, 546

1822 Rhinoceros leptorhinus Cuvier, 71-85, 88, 93, pl. IX, X, XI

1822 Rhinoceros leptorhinus Cuvier, 71-85, 88, 93, pl. IX, X, XI

1867 Ceratorhinus monspellianus Gray, 1023

1878 Atelodus (Mesorhinoceros) leptorhinus Brandt, 59 1894 Rhinoceros megarhinus Capellini, 8-13, pl. I, II see Guérin et al. (1969) for a more complete synonymy list.
Type material Skull with mandible $\left(\mathrm{n}^{\circ}\right.$ AC 2683) described and figured by De Christol (1834) stored at Natural History Museum Paris.

Type horizon Early Pliocene.

Type locality Montpellier (Hérault, France).

Diagnosis (following De Christol 1834; Guérin 1980) Large-sized two-horned rhino characterized by a massive skull with thick and long nasal bones, by the absence of a nasal septum, by a slightly vertical occipital face, and by a large occipital crest with a slight concavity in the middle. The mandible has a long symphysis and long horizontal ramus. The anterior border of the vertical ramus is inclined backwards. Nonfunctional but obvious lower incisors are present. Long bones are massive and large, third metapodials are long and flat.

Remarks D. megarhinus has generally been referred to the genus Dicerorhinus, represented by the extant species Di. sumatrensis. The latter species shows several primitive characteristics also recognized in the fossil species. However, Di. sumatrensis differs from D. megarhinus in its smaller size, shorter nasal bones, concave lower margin of the nasal bones, in a generally more posterior position of the upper tooth-row and consequently in a different position of the posterior border of the nasal notch, of the infra-orbital foramen and the anterior border of the orbital cavity, in the presence of a marked metacone style in the upper premolars, in the absence of crista and, generally, of the crochet in the upper premolars.

Referred material The material includes fragmentary mandibles and fragmentary post-cranial elements collected in several localities of Val di Pugna (MSNAF), isolated teeth from Dusino-San Paolo (MGPT) and Montelungo (MGC), fragmentary mandibles from Monte Biancano (MPPB), Palaia and S. Regolo (MGPF) and several other remains collected at Montezago, Rio Secco (MGC), Colle della Casazza (MGC), Monte Giogo (MPP) and Palaia (MGPF) (Table 1). 
Description and comparison

Val di Pugna, Fangonero-Buca and Montarioso (Siena, Tuscany)

Several remains of rhino have been recovered at Fangonero-Buca and other localities of Val di Pugna. The fossiliferous level was chronologically correlated to the Early Pliocene (MN14) and the rhinoceros remains were referred to Rhinoceros or Dicerorhinus megarhinus by Cuscani Politi (1963b, 1973, 1977) and Guérin (1980). Some of these specimens were referred to $S$. jeanvireti by Bianucci et al. (2001).

A fragmentary mandible with $\mathrm{P} 4 /, \mathrm{M} 1 /$ and M2/ (MSNAF4743; Figs. 2, 3; Tables 2, 3, 4) has a ventral profile slightly convex. $\mathrm{P} 4$ / has a V-shaped lingual valleys; mesial and slight buccal cingula are present; the difference in height between the bottoms of the valleys in this tooth is relatively important. M1/ and M2/ have a broad V-shaped lingual valleys, the differences in height between the bottoms of the valleys are relatively important. Slight lingual cingula occur below the bottoms of the lingual valleys in M2/. The vestibular syncline is deep in all the teeth. The dimensional values of the fragmentary mandible and of teeth are close to both $D$. megarhinus and $S$. jeanvireti. However, the morphology of the lingual valley and the presence of the cingula allow to refer the fragmentary mandible to D. megarhinus.

A fragmentary mandible with two horizontal rami (MSNAF4747; Figs. 2, 3; Tables 2, 3, 4) shows morphometric values close to the mean of $S$. jeanvireti and $S$. etruscus and to the minimal values of D. megarhinus. The premolars are slightly longer than in $S$. jeanvireti and $S$. etruscus. The dimensions of $\mathrm{P} / 2$ are very close to the values of $S$. etruscus and to the minimal values of D. megarhinus; they are larger than $S$. jeanvireti. $\mathrm{P} / 3$ is dimensionally close to the maximal values of $S$. etruscus and $S$. jeanvireti and to the mean values of $D$. megarhinus. $\mathrm{P} / 4$ and $\mathrm{M} / 1$ are dimensionally close to the maximal values of $S$. etruscus, $S$. jeanvireti and the mean of D. megarhinus. Incisor alveoli are relatively large (transverse diameter $=15.7 \mathrm{~mm}$ ). P/3 and $\mathrm{P} / 4$ have buccal cingula; a mesial cingulum is present in $M / 1$. Distal cingula are present in the premolars and a slight mesial cingulum occurs in $\mathrm{P} / 2$. The presence of large incisor alveoli allows to exclude an attribution to $S$. jeanvireti and S. etruscus. Furthermore, the ventral profile of the horizontal ramus of the mandible appears to be less convex below the molars than in S. jeanvireti, and the area of the diastema is more massive than in the samples from Vialette. The mandible from Fangonero is morphologically similar to $D$. megarhinus than to the other species.

The vestibular wall of an M1/ or M2/ (MSNAF4555) shows marked folds; moreover, the area of the metacone is concave. These features are recognized in D. megarhinus but a clear specific attribution is problematic.

The fragmentary distal epiphysis of a humerus (MSNAF7100) is dimensionally close to the mean value of D. megarhinus and it is larger than S. etruscus (Table 5); moreover, the oleocranic fossa appears larger than in $S$. jeanvireti and the bone is more massive than in $S$. jeanvireti and S. etruscus.

The proximal epiphysis of a humerus (MSNAF7101; Fig. 4) has the proximal transverse diameter close to the maximal values of D. megarhinus and it is larger than $S$. jeanvireti and S. etruscus (Table 5). In proximal view, the articular surface appears slightly more rounded than in $S$. jeanvireti and the posterior groove is less marked than in $S$. jeanvireti and it is similar to that of D. megarhinus. Moreover, the intertuberal groove is regularly concave in $S$. jeanvireti while in the studied specimen and in D. megarhinus it appears more angular.

The distal half of a radius (MSNAF4754) is very damaged; in distal view, the external outline of the articular surface is linear while the posterior outline is slightly concave in its external half; the external tuberosity of the anterior face is rounded and large. These features are closer to D. megarhinus than to any other Pliocene species (cf. Guérin 1972).

Other rhino remains from Fangonero-Buca are very damaged and fragmented; a specific attribution of these remains appears impossible.

A fragmentary mandible (IGF5957v; Fig. 2) stored at MGPF shows the same fossilization status than the specimens recovered at Fangonero and its label reports the indication "Pliocene of Siena". The teeth $(\mathrm{P} / 4, \mathrm{M} / 1$ and $\mathrm{M} / 2$ ) have vestibular and mesial cingula; their dimensions fall into the range of $D$. megarhinus and are close to the maximal values of $S$. jeanvireti (Tables 2, 4).

A large-sized calcaneum (MSNAF4531) stored at the MSNAF has been collected from Senese, an undefined locality near Siena. The dimensions of this remain fall into the range of D. megarhinus and S. jeanvireti (Table 5) and it can be referred to D. megarhinus based on its morphological traits. In particular, in lateral view, the posterior border is slightly convex while in $S$. jeanvireti a concavity at the level of the beak is present; in posterior view, the tuber calcanei is more massive than in $S$. jeanvireti; furthermore, in the same view, the articular surface for the cuboid is obvious and its superior border is nearest to the sustentaculum tali than in S. jeanvireti. In articular view, the medio-distal articular surface for the astragalus is small, high and has a rectangular shape while in $S$. jeanvireti it is longer and elliptical in shape.

Finally from the locality of Montarioso, two lower premolars ( $\mathrm{P} / 2$ and $\mathrm{P} / 3$; MSNAF4761), belonging to the same individual, and two upper molars (MSNAF7000 and 


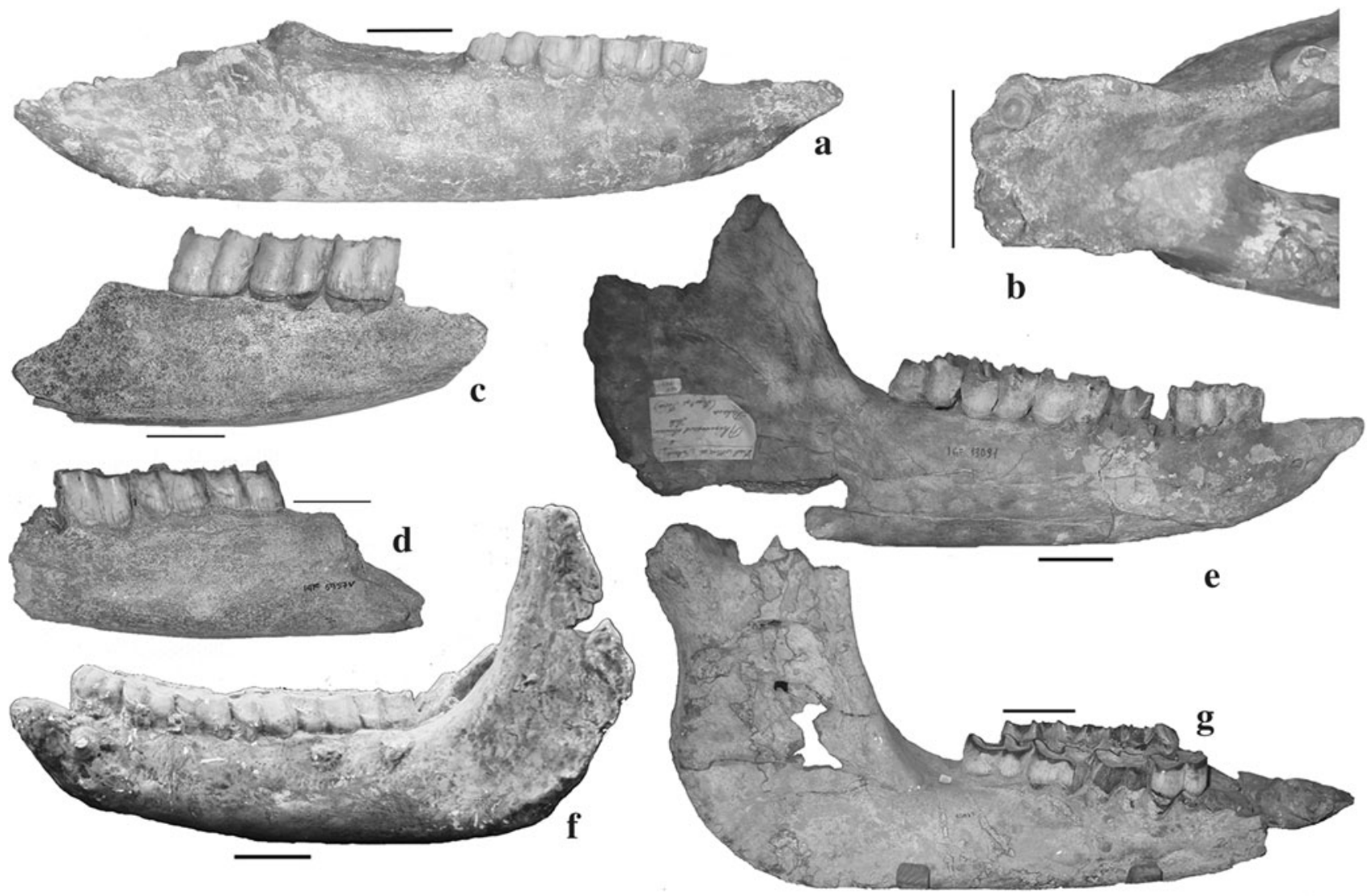

Fig. 2 Rhinoceros mandibles from the Pliocene sites of Italy: fragmentary mandible MSNAF4747 from Val di Pugna, in buccal view (a), incisive corpus of the mandible MSNAF4747 from Val di Pugna in dorsal view (b), fragmentary mandible MSNAF4743 from Val di Pugna, in buccal view (c), fragmentary mandible IGF5957v from the Pliocene of Siena, in buccal view (d), fragmentary mandible IGF5566v from Palaia, in buccal view (e); fragmentary mandible MGC9352 from Monte Pulgnasco, in buccal view (f); almost complete mandible MGC9354 from Monte San Pietro, in buccal view (g). Scale bar $5 \mathrm{~cm}$
Fig. 3 Ratio diagram for the mandibles from Monte San Pietro (MGC9354), Palaia (IGF13091), Lucardo (IGF1450v) and Val di Pugna (MSNAF4747 and MSNAF4743) (standard Diceros bicornis). The specimens are compared with the mean values of $D$. megarhinus, $S$. jeanvireti and $S$. etruscus (data from Guérin 1980). ***8Abbreviations in Table 2

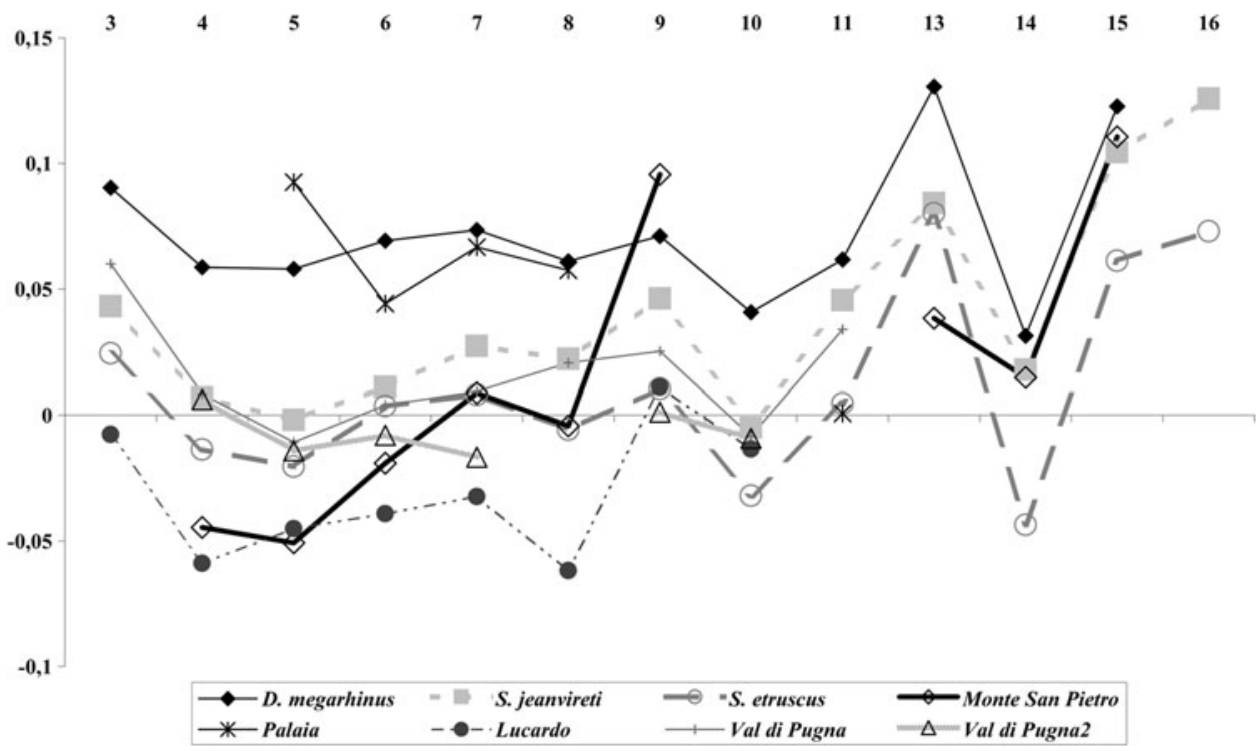

MSNAF7100) have also been recovered. The lower teeth have vestibular and mesial cingula; the anterior and posterior lingual valleys in $\mathrm{P} / 2$ have a $\mathrm{V}$-shaped morphology.
The dimensions of the teeth fall into the range of $D$. megarhinus and they are close to the maximal values of $S$. jeanvireti given by Guérin (1980) (Table 4). The presence 
Table 2 Dimensions (in mm) of the mandibles from Val di Pugna (MSNAF4747 and MSNAF4743), Monte San Pietro (MGC9354), Palaia (IGF13091), Lucardo (IGF1450v), Senese (IGF5957v), Capannoli (IGF1449v) and D. megarhinus, S. jeanvireti and S. etruscus (data from Guérin 1980)

\begin{tabular}{|c|c|c|c|c|c|c|c|c|c|c|c|c|c|}
\hline Site & Specimen & 3 & 4 & 5 & 6 & 7 & 8 & 9 & 10 & 11 & 13 & 14 & 15 \\
\hline Val di Pugna & MSNAF4747 & 71.99 & 75.66 & 77.96 & 82.85 & 86.13 & 96.5 & 50.02 & 51.71 & 117.93 & & & \\
\hline Val di Pugna & MSNAF4743 & & 75.28 & 77.34 & 80.6 & 81.11 & & 47.33 & 51.6 & & & & \\
\hline $\begin{array}{l}\text { Monte San } \\
\text { Pietro }\end{array}$ & MGC9354 & & 66.97 & 71.07 & 78.56 & 86 & 91.11 & 58.82 & 68.2 & & 129.93 & 103.5 & 245.11 \\
\hline Palaia & IGF13091 & & & 87.94 & 90.88 & 98.28 & 105 & & & 109.24 & & & \\
\hline Lucardo & IGF1450v & $61.6 \mathrm{ca}$ & $64.8 \mathrm{ca}$ & $72 \mathrm{ca}$ & $75 \mathrm{ca}$ & 78.24 & 79.8 & 48.43 & 51.1 & & & & \\
\hline Senese & IGF5957v & & 74.88 & 83.07 & 86.28 & 85.37 & & 53.14 & 53.8 & & & & \\
\hline Capannoli & IGF1449v & $59 \mathrm{ca}$ & & & & $90 \mathrm{ca}$ & $90 \mathrm{ca}$ & & & & & & \\
\hline $\begin{array}{l}D . \\
\quad \text { megarhinus }\end{array}$ & $\min -\max$ & $56-94$ & 64-106 & $74-117$ & $85-112$ & $86.5-120$ & $87-127$ & $48-70$ & $46-72$ & $101-149$ & $140-184$ & $100-115$ & $236-284$ \\
\hline S. jeanvireti & $\min -\max$ & $61.5-77$ & $70-82$ & $74-85$ & $71-92$ & $77-99$ & $90-105$ & $45-60.5$ & $43.5-69$ & 114-133 & $135.5-163$ & $92-115$ & $220-270$ \\
\hline S. etruscus & $\min -\max$ & $55.5-80$ & $62.5-83.5$ & $64-85.5$ & $65-91$ & $70-96.5$ & $79-105$ & $41-60$ & $41-60$ & $94-123$ & $115-152$ & $77.5-107$ & $182-243$ \\
\hline
\end{tabular}

The measurement is taken according to the methodology exposed by Guérin (1980)

3-8 height of the horizontal ramus, respectively, at the level of P/2-P/3, P/3-P/4, P/4-M/1, M/1-M/2, M/2-M/3, rear of M/3; 9-10 width of the horizontal ramus, respectively, at the level of $\mathrm{P} / 4-\mathrm{M} / 1$ and $\mathrm{M} / 2-\mathrm{M} / 3 ; 11$ length of the symphysis; 13 antero-posterior diameter of the vertical ramus; 14 transverse diameter of the articular condyle; 15 height of the condyle

Table 3 Dimensions (in mm) of the lower cheek teeth from Val di Pugna (MSNAF4747 and MSNAF4743), Monte Pulgnasco (MGC9352) (data from Simonelli 1897), Monte San Pietro (MGC9354), Palaia (IGF13091), Lucardo (IGF1450v), Capannoli (IGF1449v) and D. megarhinus, S. jeanvireti and S. etruscus (data from Guérin 1980)

\begin{tabular}{|c|c|c|c|c|c|c|c|c|c|}
\hline Site & Specimen & Lbt & Llt & Lbm & Llm & Lbp & Llp & Lbp3-p4 & Llp3-p4 \\
\hline Val di Pugna & MSNAF4747 & $244.65 \mathrm{ca}$ & & $139 \mathrm{ca}$ & & $110.17 \mathrm{ca}$ & 106.63 & 78.43 & 75.57 \\
\hline Monte Pulgnasco & MGC9352 & 232 & & 128 & & 104 & & $75 \mathrm{ca}$ & \\
\hline Monte San Pietro & MGC9354 & & & 138.9 & 134 & & & & \\
\hline Palaia & IGF13091 & 254.81 & 254.93 & 144.97 & 144.13 & $113.34 \mathrm{ca}$ & & $83 \mathrm{ca}$ & \\
\hline Lucardo & IGF1450v & & & $135.30 \mathrm{ca}$ & & & & & \\
\hline Capannoli & IGF1449v & $234.70 \mathrm{ca}$ & & 133.15 & 127.76 & $108 \mathrm{ca}$ & & $78.32 \mathrm{ca}$ & \\
\hline D. megarhinus & $\min -\max$ & $228-293$ & & $134-165$ & & $101-136$ & & $71-91$ & \\
\hline S. jeanvireti & $\min -\max$ & $234-242$ & & $127-138$ & & $98-106$ & & $69.5-77$ & \\
\hline S. etruscus & $\min -\max$ & $210-251.5$ & & $121-143$ & & $87-108$ & & $63-80.5$ & \\
\hline
\end{tabular}

$L b t$ total buccal length of the tooth-row, Llt total lingual length of the tooth-row, Lbm buccal length of the molars, $L l m$ lingual length of the molars, $L b p$ buccal length of the premolars, Llp lingual length of the premolars, Lbp3-p4 buccal length of the last two premolars; Llp3-p4 lingual length of the last two premolars

of the cingula and the length of the premolars allow to exclude an attribution to $S$. jeanvireti, while the presence of the anterior lingual valley in $\mathrm{P} / 2$ allows to exclude an attribution to $S$. etruscus. This last morphological feature can be recognized in some specimens of $D$. megarhinus (e.g. in the $\mathrm{P} / 2$ of the mandible from Palaia) as the presence of the above-mentioned cingula. Two upper molars can be referred to the same species. The latter teeth have a marked and large paracone fold, a wavy profile of the vestibular wall, crista and a slight lingual cingulum. In $S$. jeanvireti, the vestibular wall of the upper molars (in particular M1/) is less wavy than in D. megarhinus and has a slight paracone fold, while crista and cingula are generally absent (cf. Guérin 1980).

\section{Colle della Casazza (Bologna, Emilia-Romagna)}

A fragmentary proximal epiphysis of a humerus (MGC1870) has been collected from the Pliocene sands outcropping at Colle della Casazza (Capellini 1894). The proximal transverse diameter overlaps the maximal values of $S$. jeanvireti and S. etruscus and it is close to the mean values of D. megarhinus (Table 5); moreover, the articular surface appears more rounded than in $S$. jeanvireti.

\section{Dusino-San Paolo (lower levels)}

The teeth (first and second molars and fourth premolar; one isolated upper premolar) recovered in the lower levels at 
Table 4 Dimensions (in $\mathrm{mm}$ ) of the teeth from Val di Pugna (MSNAF4747 and MSNAF4743), Senese (IGF5957v), Monte San Pietro (MGC9354), Monte Pulgnasco (MGC9352) (data from

\begin{tabular}{|c|c|c|c|c|c|c|c|c|c|c|}
\hline Site & Specimen & Tooth & Lmax & Dtmax & $\mathrm{Lb}$ & $\mathrm{Ll}$ & TDd & $\mathrm{TDm}$ & Hav & $H_{\mathrm{pv}}$ \\
\hline Val di Pugna & MSNAF4747 & $\mathrm{P} / 2$ & 31.73 & 19.05 & 31.44 & 28.19 & 19.16 & 14.75 & & \\
\hline Val di Pugna & MSNAF4747 & $\mathrm{P} / 3$ & 40.05 & 25.83 & 38.42 & 35.12 & 25.5 & 21.25 & & \\
\hline Val di Pugna & MSNAF4747 & $\mathrm{P} / 4$ & 42.43 & 30.51 & 39.35 & 38.52 & 29 & 25.28 & & \\
\hline Val di Pugna & MSNAF4747 & $\mathrm{M} / 1$ & 48.85 & $29.60 \mathrm{ca}$ & 42.13 & & & $26.20 \mathrm{ca}$ & & \\
\hline Val di Pugna & MSNAF4743 & $\mathrm{P} / 4$ & 39.41 & 28.7 & 39.89 & 35.2 & 27.71 & 25.96 & 20.65 & 16.14 \\
\hline Val di Pugna & MSNAF4743 & $\mathrm{M} / 1$ & 44.22 & 30.3 & 42 & 38.77 & 27 & 28.9 & 23.1 & 15.91 \\
\hline Val di Pugna & MSNAF4743 & $\mathrm{M} / 2$ & 49.02 & 30.61 & 45.22 & 42.9 & 27.89 & 29.12 & 20.42 & 16.2 \\
\hline Val di Pugna & MSNAF4761 & $\mathrm{P} / 2$ & 31.88 & 18.50 & & & & & & \\
\hline Val di Pugna & MSNAF4761 & $\mathrm{P} / 3$ & 37.60 & & & & & & & \\
\hline Senese & IGF5957v & $\mathrm{P} / 4$ & 41.16 & 30.17 & 39.77 & 38 & & & & \\
\hline Senese & IGF5957v & $\mathrm{M} / 1$ & 47.33 & 32.2 & 43.76 & 44.11 & & & & \\
\hline Senese & IGF5957v & $\mathrm{M} / 2$ & 49 & 32.73 & 44.71 & 44.05 & & & & \\
\hline Monte San Pietro & MGC9354 & $\mathrm{P} / 4$ & & $29.37 \mathrm{ca}$ & 42.33 & & & & & \\
\hline Monte San Pietro & MGC9354 & $\mathrm{M} / 1$ & 44.4 & $33.61 \mathrm{ca}$ & 42.64 & & & & & \\
\hline Monte San Pietro & MGC9354 & $\mathrm{M} / 2$ & 48.63 & 32.69 & 46.87 & & & & & \\
\hline Monte San Pietro & MGC9354 & $\mathrm{M} / 3$ & 54.97 & 33.37 & 49.6 & & & & & \\
\hline Monte Pulgnasco & MGC9352 & $\mathrm{P} / 2$ & $29-28.4$ & 19-19 & & & & & & \\
\hline Monte Pulgnasco & MGC9352 & $\mathrm{P} / 3$ & 36 & 30.3 & & & & & & \\
\hline Monte Pulgnasco & MGC9352 & $\mathrm{P} / 4$ & 38 & 29.3 & & & & & & \\
\hline Monte Pulgnasco & MGC9352 & $\mathrm{M} / 1$ & $42.3-42.5$ & $32-32$ & & & & & & \\
\hline Monte Pulgnasco & MGC9352 & $\mathrm{M} / 2$ & $44.7-44$ & $31-32$ & & & & & & \\
\hline Monte Pulgnasco & MGC9352 & $\mathrm{M} / 3$ & $43-41$ & $29.4-29$ & & & & & & \\
\hline Palaia & IGF13091 & $\mathrm{P} / 2$ & 28.6 & 17.92 & 28.41 & 27.95 & & & & \\
\hline Palaia & IGF13091 & $\mathrm{P} / 3$ & 39.42 & 24.6 & 35.95 & 33.52 & & & 19.95 & 14.42 \\
\hline Palaia & IGF13091 & $\mathrm{P} / 4$ & 42.52 & 27.66 & 43.5 & 39.63 & & & 17.3 & 10.24 \\
\hline Palaia & IGF13091 & $\mathrm{M} / 1$ & 48.65 & 31.16 & 47.39 & 44.94 & & & 19.23 & 12.77 \\
\hline Palaia & IGF13091 & $\mathrm{M} / 2$ & 52.24 & 32 & 45.25 & 45.39 & & & 16 & 13.22 \\
\hline Palaia & IGF13091 & $\mathrm{M} / 3$ & 49.12 & 35 & 44.45 & 45.36 & & & 14.91 & 13.61 \\
\hline D. megarhinus & $\min -\max$ & $\mathrm{P} / 2$ & $29.5-43$ & $16.5-25$ & & & & & & \\
\hline D. megarhinus & $\min -\max$ & $\mathrm{P} / 3$ & $35-44$ & $22.31,5$ & & & & & & \\
\hline D. megarhinus & $\min -\max$ & $\mathrm{P} / 4$ & $37.5-48$ & $27.5-38$ & & & & & & \\
\hline D. megarhinus & $\min -\max$ & $\mathrm{M} / 1$ & $38.5-53$ & $29-40$ & & & & & & \\
\hline D. megarhinus & $\min -\max$ & $\mathrm{M} / 2$ & $43-57.5$ & $31-39$ & & & & & & \\
\hline D. megarhinus & $\min -\max$ & $\mathrm{M} / 3$ & $48-62$ & $29.5-37$ & & & & & & \\
\hline S. jeanvireti & $\min -\max$ & $\mathrm{P} / 2$ & $27-28.5$ & $16.5-19$ & & & & & & \\
\hline S. jeanvireti & $\min -\max$ & $\mathrm{P} / 3$ & $33-38$ & $23-27$ & & & & & & \\
\hline S. jeanvireti & $\min -\max$ & $\mathrm{P} / 4$ & $37-40.5$ & $24-31$ & & & & & & \\
\hline S. jeanvireti & $\min -\max$ & $\mathrm{M} / 1$ & $42-47$ & $28-34$ & & & & & & \\
\hline S. jeanvireti & $\min -\max$ & $\mathrm{M} / 2$ & $43-50$ & $27-33$ & & & & & & \\
\hline S. jeanvireti & $\min -\max$ & $\mathrm{M} / 3$ & $43.5-51$ & $26-33$ & & & & & & \\
\hline S. etruscus & $\min -\max$ & $\mathrm{P} / 2$ & $25-33$ & $16-21.5$ & & & & & & \\
\hline S. etruscus & $\min -\max$ & $\mathrm{P} / 3$ & $31.5-37$ & $21.5-29$ & & & & & & \\
\hline S. etruscus & $\min -\max$ & $\mathrm{P} / 4$ & $35-39.5$ & $24-31$ & & & & & & \\
\hline S. etruscus & $\min -\max$ & $\mathrm{M} / 1$ & $37-43$ & $26.5-33$ & & & & & & \\
\hline S. etruscus & $\min -\max$ & $\mathrm{M} / 2$ & $40.5-47.5$ & $37-33.5$ & & & & & & \\
\hline S. etruscus & $\min -\max$ & $\mathrm{M} / 3$ & $41-50$ & $26-33$ & & & & & & \\
\hline
\end{tabular}

Lmax maximal length, Dtmax maximal transverse diameter, $L b$ buccal length, $L l$ lingual length, $T D d$ distal transverse diameter, $T D m$ mesial transverse diameter, Hav height of the anterior lingual valley, $H p v$ height of the posterior lingual valley
Simonelli 1897), Palaia (IGF13091) and D. megarhinus, S. jeanvireti and S. etruscus (data from Guérin 1980) 
Dusino-San Paolo have been described and figured by Sacco (1906; Tav. 1, Figs. 1 and 2). Guérin (1980) ascribed these remains to $D$. megarhinus. The teeth of the upper tooth-row are brachydont, with a wavy vestibular wall and a large paracone fold; an attribution to D. megarhinus can be confirmed. The isolated upper premolar is very worn and a specific attribution of this remain appears problematic.

\section{Montelungo (Bologna, Emilia-Romagna)}

The upper molar (MGC sn) figured by Capellini (1894) shows morphological characteristics close to D. megarhinus. In particular, the tooth is brachydont with a welldeveloped mesial cingulum and a single crista.

\section{Monte Biancano (Bologna, Emilia-Romagna)}

The fragmentary mandible from Monte Biancano, stored at the Museum of Palazzo Poggi (Bologna) has been figured and described by several authors, including Cuvier (1822), De Christol (1834) and Capellini (1894). The remain has four incisor alveoli and a relatively long symphysis; in agreement with the above-mentioned authors and Guérin (1980), the remain can be referred to D. megarhinus.

\section{Monte Giogo (Piacenza, Emilia-Romagna)}

A partial skeleton of a large-sized rhinoceros has been recovered at Monte Giogo and it is stored at the Museum of Paleontology, University of Parma. The remains were extensively described by Simonelli (1897) and they were referred to Rhinoceros megarhinus. The morphology of the upper teeth is very close to the specimens from Montpellier, the nasal bones lack of the nasal septum and the postcranial remains are morphologically similar to the typical specimens of D. megarhinus. The upper teeth are brachydont with a relatively wavy vestibular wall; crista and crochet are present. $\mathrm{P} 4 /$ has a multiple crochet while P2/ has a close mediofossette. The horizontal ramus of the fragmentary mandible is relatively high with an inflexion at the level of the $\mathrm{P} / 3$. The humerus has a marked anteroposterior crest in the lateral side of the distal epiphysis; the oleocranic fossa appears large and the epicondyles are massive. The metapodials are relatively long and the astragalus has a high and massive medial tuberosity, the central depression below the trochlear trough is marked and the anterior border of the distal articular surface, in distal view, is linear. The dimensions of the remains are close to the mean values of $D$. megarhinus given by Guérin (1980). 


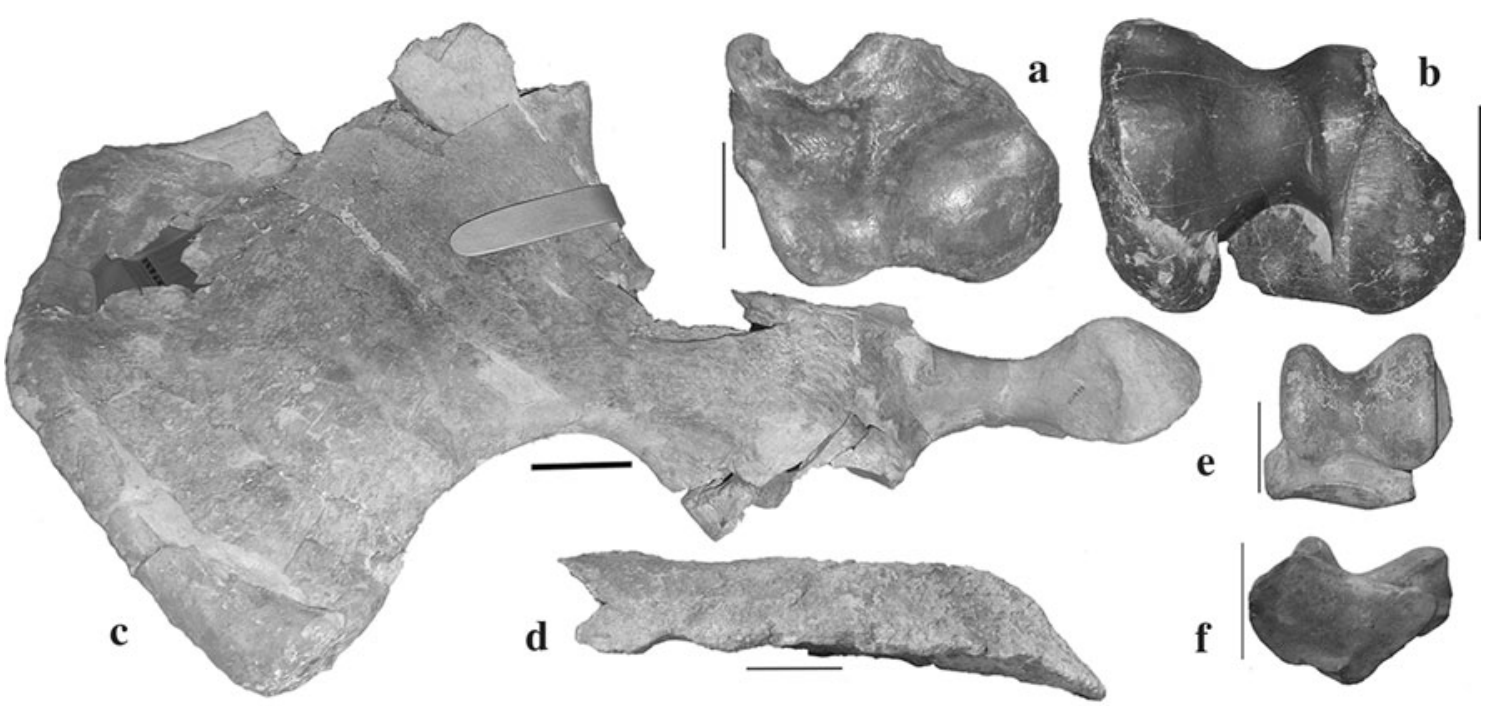

Fig. 4 Selected rhinoceros remains from the Pliocene sites of Italy: proximal epiphysis of humerus (MSNAF7100) from Val di Pugna in proximal view (a), distal epiphysis of humerus from Monte Pastore (MGC sn) in distal view (b), pelvis (MGC9350) from Rio Secco in

\section{Montezago (Piacenza, Emilia-Romagna)}

The rhino from Montezago was described first by Cortesi (1819) and later by Cuvier (1822) and Falconer (1868). Unfortunately, the specimen was destroyed in 1944. In the skull figured by Cuvier (1822; Pl. 47, Fig. 7) and described by Falconer (1868; p. 381) "there is not the slightest indication of a dividing nasal septum" (Falconer 1868; p. 388), the occipital crest is not much projected backwards, "the occipital face inclines a little forwards as it ascends from the occiput upwards", "the orbits are placed immediately over the sixth tooth", the complex crochet in the fourth upper premolar is present, the enamel of the teeth is smooth. All these characteristics allow to refer the specimen to $D$. megarhinus. Guérin (1980) ascribed, with reserve, a cast of a fore limb stored at the Museum of Geology G. Capellini to the rhino from Montezago. However, no indications are reported on the cast and the specimen is not mentioned by Capellini (1894) in the list of the rhino remains stored at the MGC. Due to the impossibility to known the original site and to study some morphological traits (the elements of the cast are glued), the cast is not considered in this work.

\section{Palaia (Lower Valdarno, Tuscany)}

Azzaroli (1962) and Guérin (1980) recorded the occurrence of D. megarhinus at Palaia (Lower Valdarno). A fragmentary nasal bone without the presence of a nasal septum (IGF5566v) can be referred to this species together with an almost complete mandible (IGF13091) (Figs. 3, 4). In the dorsal view (c), nasal bones (IGF5566v) from Palaia in lateral view (d), astragalus (MGC sn) from Pradalbino in anterior (e) and distal view (f). Scale bar $5 \mathrm{~cm}$

latter specimen, the ventral profile of the horizontal ramus is slightly convex below the premolars. The symphysis is long, its rear border is at the level of $\mathrm{P} / 3$ and, in the anterior border, four incisor alveoli are present. The lower cheek tooth-row is slightly longer than in $S$. jeanvireti and $S$. etruscus, while the high of the horizontal ramus is close to the mean values of $D$. megarhinus and the maximal values of S. etruscus and S. jeanvireti (Tables 2, 3, 4).

\section{Rio Secco (Bologna, Emilia-Romagna)}

An almost complete pelvis (MGC9350) has been recovered from the Pliocene sands at Rio Secco (Capellini 1894) (Fig. 4). An attribution to S. etruscus can be ruled out because of the large size of the specimen and the presence of some morphological differences. Moreover, the acetabulum is elliptical in shape as in D. megarhinus, while it appears more rounded in $S$. jeanvireti.

\section{Regolo (Lower Valdarno, Tuscany)}

The hemimandible from S. Regolo has a very large dimensions (Azzaroli 1962; Tav. VII, Fig. 3, Tav. XI, Fig. 5). The ventral profile of the horizontal ramus is slightly convex with an inflexion at the level of $\mathrm{M} / 1-\mathrm{P} / 4$; the molars and the two last premolars are longer than in $S$. jeanvireti. According to Guérin (1980), the specimen can be referred to an evolutionary stage of the D. megarhinus.

Genus Stephanorhinus Kretzoi, 1942 
Type species Rhinoceros etruscus Falconer 1868 from the Upper Valdarno, Early Pleistocene.

Other species Stephanorhinus jeanvireti (Guérin 1972), Stephanorhinus hundsheimensis (Toula 1902), Stephanorhinus hemitoechus (Falconer 1859), Stephanorhinus kirchbergensis (Jäger 1839) and maybe "S." miguelcrusafonti (Guérin and Santafé-Llopis 1978). Recently Tong (2012) included in this genus the species $S$. yunchuchenensis (Chow 1963) and S. lantianensis (Hu and Qi 1978).

Diagnosis Two-horned rhinos. Presence of a partially ossified nasal septum. Molarised premolars. No functional incisors. According to Fortelius et al. (1993), the genus Brandtorhinus Guérin 1980 is identical to Stephanorhinus Kretzoi, 1942 and the latter name "is preferable to Guérin's because it has priority and has been used quite extensively in literatures".

Referred material To Stephanorhinus sp. are referred a fragmentary mandible from Lucardo (MGPF) and fragmentary material from Monte Tiffi (MGC).

Description and comparison

\section{Lucardo (near Montopoli, Lower Valdarno, Tuscany)}

A fragmentary mandible (IGF1450v) was ascribed to Rhinoceros megarhinus by Azzaroli (1962). The teeth (M2/ , M1/ and P3/) are very wear and the mandible is poorly preserved. The ventral profile of the mandible below the premolars is slightly convex. The length of the molars, approximately of $135 \mathrm{~mm}$, is close to the minimal values of $D$. megarhinus and falls into the range of $S$. jeanvireti and S. etruscus (Tables 2, 3). The mandible is less high and less thick than in D. megarhinus. Moreover, the relative proportions and dimensions of the mandible are close to $S$. jeanvireti and S. etruscus (Fig. 3). However, due to the conservation status of the remain, a specific attribution appears very difficult.

\section{Monte Tiffi (Forli-Cesena, Emilia-Romagna)}

Two fragmentary teeth, one distal epiphysis of a second metacarpal and the external half of one astragalus (MGC sn), have been collected from a lignite bed at Monte Tiffi (Simonelli 1919). The talus is dimensionally close to the values of $S$. jeanvireti and it is larger than $S$. etruscus (Table 6). Morphologically, it shows some similarities with $S$. jeanvireti but a sure specific attribution appears uncertain.

\section{Species Stephanorhinus jeanvireti (Guérin 1972)}

Synonymy list 1828 Rhinoceros elatus Croizet and Jobert, 144-165, pl. I fig. 7, pl. IV figs. 3-7, pl. V figs. 1-4, pl. Vi fig. 1, pl. XI figs. 1-6, pl. XII figs. 1-2, 8

1895 Rhinoceros etruscus var. astensis Sacco, 1-31, pl. I-IV

see Guérin (1972) for a more complete synonymy list.

Type material Skull and mandible ( ${ }^{\circ} \mathrm{Vt}$ 627) described and figured by Guérin (1972), stored at Natural History Museum Basel.

Type horizon Late Pliocene

Type locality Vialette (Haute-Loire, France).

Diagnosis (mostly translated from Guérin 1972, 1980) Large-sized rhino. Nasal septum ossified anteriorly. Postorbital, sus-orbital and pre-orbital apohysises well marked. Occipital face slightly vertical. Occipital crest large and with a marked transverse concavity. Post-glenoid apophysis strong and forwards. Paraoccipital apophysis more developed than the post-tympanic one. Mandible with long symphysis, horizontal ramus relatively long. Absence of anterior teeth.

Referred material Fragmentary mandibles from Monte Pulgnasco (MGC and MGPF cast), Capannoli (MGPF) and Monte San Pietro (MGC), astragalus from Pradalbino (MGC), fragmentary humerus from Monte Pastore (MGC),

Table 6 Dimensions (in mm) of the astragali from Pradalbino (MGC sn), Monte Tiffi (MGC sn) and D. megarhinus, S. jeanvireti and S. etruscus (data from Guérin 1980 and Fortelius et al. 1993)

\begin{tabular}{llllllllll}
\hline Site & Specimen & Hmax & Hm & Hl & Dtmax & DTD & DTDa & DAPm & DAPl \\
\hline Pradalbino & MGC sn & 89.02 & 79.21 & 82.03 & 96.06 & 75.89 & 73.73 & 61.33 & 45.65 \\
Monte Tiffi & MGC sn & & & 83.35 & & & & 41.16 \\
D. megarhinus & min-max & $88-110$ & $81.42-97.6$ & $84.53-96.79$ & $92.5-113$ & $78-99$ & $71-91$ & $59-76$ & $46.72-51.51$ \\
S. jeanvireti & $\min -\max$ & $87-104$ & $80.81-96.57$ & $83.55-97.92$ & $92-107.5$ & $77-94$ & $70-85$ & $60-72$ & $42.96-53.97$ \\
S. etruscus & $\min -\max$ & $71-84$ & $65-74$ & $70-74$ & $73-88$ & $60-78$ & $57-75$ & $47-58$ \\
\hline
\end{tabular}

The range values of $\mathrm{Hm}, \mathrm{Hl}$ and DAPl for the astragali of $D$. megarhinus $(N=7)$ and $S$. jeanvireti $(N=6)$ are based on the material studied at NMB. The range values of $\mathrm{Hm}$ and $\mathrm{Hl}$ for the astragali of $S$. etruscus are from Fortelius et al. (1993)

Hmax maximal height, $\mathrm{Hm}$ medial height, $\mathrm{Hl}$ lateral height, Dtmax maximal transverse diameter, DTD distal transverse diameter, $D T D a$ distal articular transverse diameter, $D A P m$ medial antero-posterior diameter, $D A P l$ lateral antero-posterior diameter 
several post-cranial bones, fragmentary skull and teeth from Montopoli (MGPF) (Table 1).

\section{Description and comparison}

\section{Monte Pulgnasco (Piacenza, Emilia-Romagna)}

The original mandible from Monte Pulgnasco was destroyed during the 1862 and was discussed and figured by Simonelli (cf. Simonelli 1897). However, a cast of the original remain is preserved at the MGC (MGC9352) and at the MGPF (IGF4684) (Fig. 2); the latter was figured by Simonelli (1897; Tav. XIV, figs 1-3). The mandible is damaged in the posterior margin of the vertical ramus and the incisive corpus is abraded; thus, the symphysis and the diastema appear relatively shorter than in $D$. megarhinus and $S$. jeanvireti. The dimensions of the teeth and of the horizontal rami fall into the range variations of $D$. megarhinus, $S$. jeanvireti and S. etruscus (Tables 3, 4). Finally, the total length of the molars is shorter than in D. megarhinus. The ventral profile of the mandible is convex and the anterior border of the vertical ramus is slightly vertical; the ratio between the length of $\mathrm{P} / 3-\mathrm{P} / 4$ and the length of the molars is relatively high. These last characteristics appear distinctive of $S$. jeanvireti.

\section{Pradalbino (Bologna, Emilia-Romagna)}

A well-preserved astragalus (MGC sn) from Pradalbino has been discussed by Capellini (1894) (Fig. 4) which referred the specimen to Rhinoceros megarhinus. The astragalus shows dimensional values close to the minimal values of $D$. megarhinus and those of $S$. jeanvireti (Table 6). Nevertheless, morphological characteristics allow to refer the remain to $S$. jeanvireti. In particular, in anterior view, in the astragalus from Pradalbino the trochlear trough is less developed than in D. megarhinus and the central depression under the trochlear trough, obvious in D. megarhinus, is absent. In addition, in posterior view, the medio-distal articular surface with the calcaneum appears more elliptical in shape than in D. megarhinus. In distal view, the articular surface for the cuboid is slightly elongated anteriorly than that for the navicular; in medial view, the posterior border of the trochlea is generally less developed posteriorly than in D. megarhinus.

\section{Monte Pastore (Bologna, Emilia-Romagna)}

Two remains of rhinoceros, probably belong to the same individual, have been collected at Monte Pastore; a distal epiphysis and a very damaged proximal epiphysis of humerus (MGC sn) (Fig. 4; Table 5). The proximal epiphysis does not shows useful morphomological or morphometrical characteristics. In the distal epiphysis, in distal view, the medial epicondyle is rounded and massive; in the lateral side, the tuberosity is large, rounded and well developed as in $S$. jeanvireti. Finally, the transverse diameter of the distal trochlea is close to the values of $S$. jeanvireti from Vialette and it is generally smaller than the values of $D$. megarhinus.

\section{Monte San Pietro (Bologna, Emilia-Romagna)}

An almost complete mandible (MGC9354) has been recovered at Monte San Pietro and it was published by Capellini (1920) as Rhinoceros megarhinus (Fig. 2). Really, several dimensional values of the mandible and teeth are close to the minimal values of $D$. megarhinus and to the maximal values of $S$. jeanvireti (Tables 2, 3, 4). Moreover, the proportions of the mandible are more similar to $S$. jeanvireti than to D. megarhinus (Fig. 3). In addition, the high of the horizontal ramus below the premolars is shorter and the anterior border of the ascending ramus is more vertical than in D. megarhinus.

\section{Montopoli (Lower Valdarno, Tuscany)}

Azzaroli (1962) ascribed to Di. megarhinus two almost complete fore limbs, two almost complete rear limbs, two incomplete lower cheek teeth, a fragmentary skull of a young individual, a talus and a metatarsal. Guérin (1980) referred to $S$. etruscus the isolated talus and to $S$. jeanvireti the limbs, the skull and the teeth. The four almost complete limbs and the two cheek teeth (IGF1075) probably belong to the same individual and they have been recovered during the Paleontological excavations of Forsyth Major in the 1880. Based on the morphological characteristics of the specimens, the attribution to $S$. jeanvireti can be confirmed. Indeed, in the scaphoid, in anterior view, the medial profile is convex, while the lateral one in concave in the proximal half and slightly convex in the distal half; furthermore, the medial side of the bone is higher than the lateral one. In the second metacarpal, the posterior tuberosity is slightly developed and the proximal articular surface is rounded. In the third metacarpal, the anterior border of the proximal articular surface is slightly convex, the lateral articular surfaces are higher than the specimens from Montpellier and the posterior one has a sub-triangular shape. In the second metatarsal, the anterior border of the proximal articular surface extends less anteriorly than the anterior border of the epiphysis; the anterior and posterior lateral articular surfaces are similar in size but the posterior one is divided into two parts by a slight edge. In the astragalus, the medial tuberosity is massive and rounded and it is near 
the distal border of the medial face. The fragmentary skull (IGF14869), referred to $S$. jeanvireti, belongs to a young individual and it is crushed and damaged. All the upper deciduous and two erupting M1/ are present. D1/ has a very small crista, a reduced protolophe and a convex profile of the vestibular wall. D2/ has a mesial cingulum and a wavy profile of the vestibular wall. D3/ has a mesial cingulum, a protocone constriction and a wavy profile of the vestibular wall with a marked paracone fold as in D4/.

\section{Capannoli (Lower Valdarno, Tuscany)}

Azzaroli (1962) ascribed a fragmentary mandible from Capannoli (Lower Valdarno) to Di. megarhinus. According to Guérin (1980), these specimens can be really referred to $S$. jeanvireti. The dimensions of the fragmentary mandible from Capannoli (IGF1449v) fall into the range of the three Pliocene species of rhinoceros; they are close to the minimal values of $D$. megarhinus and to the mean values of $S$. jeanvireti and S. etruscus (Tables 2,3). The incisive corpus is abraded and the posterior border of the symphysis is at the level of $\mathrm{P} / 2-\mathrm{P} / 3$. The ventral profile of the horizontal ramus is convex and its height decreases abruptly in the premolar portion; unfortunately, the ventral side of the ramus below $\mathrm{M} / 2$ and $\mathrm{P} / 4$ has been partially reconstructed. The horizontal ramus appears proportionally thinner than in D. megarhinus. Buccal and mesial cingula occur in the molars and in the $\mathrm{P} / 4$; furthermore, lingual cuspules occur in the anterior lophe of the $\mathrm{P} / 4, \mathrm{M} / 2$ and $\mathrm{M} / 3$. The lingual valleys of the teeth have a $\mathrm{V}$-shaped morphology. The ratio between the estimated length of the two last premolars (only the roots of $\mathrm{P} / 3$ are present) and the length of the molars is relatively high. Based on its morphological characteristics, the specimen can be referred to $S$. jeanvireti.

Species Stephanorhinus etruscus (Falconer 1868)

Synonymy list 1868 Rhinoceros etruscus Dawkins, 207-218, pl. VII-VIII

1921 Rhinoceros etruscus Ugolini, 1-4

1963 Rhinoceros (Dicerorhinus) etruscus Cuscani Politi, 25-57 pl. I-III

1971 Dicerorhinus etruscus Guérin and Heintz, 13-22 1972 Dicerorhinus etruscus Ambrosetti, 177-198, pl. I-VII

(this is a selected list, see Guérin 1980).

Type material Skull (IGF 756) figured and described by Falconer (1868), stored at Natural History Museum, Section of Geology and Paleontology, Florence.

Type horizon Early Pleistocene

Type locality Upper Valdarno Basin (Tuscany, Italy).
Diagnosis (mostly translated from Guérin 1980) Small to medium-sized rhino. Nasal septum ossified anteriorly. Postorbital and sus-orbital apohysises are marked. Occipital face slightly inclined posteriorly and downwards. Occipital crest large and with a marked transverse concavity. Post-glenoid apophysis strong and slightly forwards. Paraoccipital apophysis less developed than the post-tympanic one. Mandible with long symphysis, horizontal ramus relatively short and high. Absence of anterior teeth.

Referred material Maxillae from Barga Basin (MSNP), nasal bones from Costa Marenga (MGC), astragalus and fragmentary metatarsus from Montopoli (MGPF) (Table 1).

Description and comparison

\section{Montopoli (Lower Valdarno, Tuscany)}

A small-sized astragalus (IGF1452v) shows a lower and less developed medial tuberosity than in $D$. megarhinus and S. jeanvireti; moreover, the anterior border of the distal articular surface has a concavity in the lateral side and the articular surface for the cuboid extends more anteriorly than that for the navicular. Finally the lateral lip of the trochlea is less developed than in D. megarhinus and S. jeanvireti. In agreement with Guérin (1980), the remain can be referred to $S$. etruscus. A fragmentary small metatarsal (IGF4688v) has also been recovered at Montopoli. The specimen lacks the distal epiphysis and it is damaged in the proximal one; it can be referred to $S$. cf. etruscus based on its small dimensions.

\section{Barga Basin (Lucca, Tuscany)}

Coltorti et al. (2008) ascribed to Stephanorhinus sp. a large-sized fragment of metapodial diaphysis. Two complete maxillae were extensively described by Ugolini (1918) and they have been recovered at Castelnuovo di Garfagnana. The maxillae, the premolars and the molars are shorter than those of $S$. jeanvireti and D. megarhinus and they are close to the values of $S$. etruscus. Moreover, the vestibular walls of the teeth are relatively flat with a slightly marked paracone folds.

\section{Costa Marenga (Salsomaggiore, Emilia-Romagna)}

The nasal bones (MGC sn) from Costa Marenga show the presence of a partial nasal septum (Simonelli 1919). This morphology allows to exclude an attribution to $D$. megarhinus. The rugosity on the dorsal side of the nasal bones is 
well developed and the rhionion is more inclined than in $S$. jeanvireti and it is similar to those of $S$. etruscus.

Rhinocerotini indet.

Few teeth collected at Sarzanello (Ponzano di Magra, Tuscany; Capellini 1913) (MGC sn) and Barga (MGC7584) show common characteristics belonging to both $D$. megarhinus and $S$. jeanvireti. They are ascribed to Rhinocerotini indet.

\section{Discussion and conclusions}

The morphological and morphometrical revision of the occurrences of Dihoplus megarhinus in Italy allows to record the species in at least ten Pliocene localities: Val di Pugna, Colle della Casazza, Rio Secco, Montelungo, Monte Biancano, Monte Giogo, Montezago, Palaia, S. Regolo and Dusino-San Paolo (lower levels). The records of the species in other Pliocene localities are unfounded and they can be really referred to $S$. jeanvireti (Monte San Pietro, Monte Pastore, Montopoli, Pradalbino, Monte Pulgnasco) or S. etruscus (Costa Marenga, Montopoli). D. megarhinus appears to be easily distinguishable from $S$. etruscus, in particular, due to the large size of its remains. In the mandibles, the two species differ in the development of the diastema and the symphysis (longer in D. megarhinus than in S. etruscus) and additionally in the presence, in D. megarhinus, of obvious, but non-functional incisors. Other differences are clear in the vertical ramus of the mandible and in the height and thickness of the horizontal ramus. Moreover, the differences between the mandibles of D. megarhinus and $S$. jeanvireti are relatively scarce and are particularly apparent in the orientation of the anterior border of the vertical ramus and partially in the morphology of the ventral border of the horizontal ramus. In addition, the two species appear to differ in the morphology of the incisive corpus, but this area is usually poorly preserved in fossil specimens. The postcranial remains of $D$. megarhinus are more easily distinguished from those of $S$. jeanvireti and $S$. etruscus than the mandibles. The limb bones of D. megarhinus are generally larger than those of the two Stephanorhinus species and show peculiar morphological characteristics. The morphological differences between the humeri, astragali and calcanei of D. megarhinus and S. jeanvireti listed by Guérin $(1972,1980)$ are confirmed by the results of this study. However, in the astragalus, the position and development of the medial tuberosity appear to be variable in $D$. megarhinus and $S$. jeanvireti, and this morphological feature is not very useful in distinguishing the two species. Unfortunately, the scarce remains of $D$. megarhinus collected from the
Italian sites do not allow an extensive morphometrical investigation for analyzing evolutionary trends or variability in the populations. Several morphometric values of the remains from Val di Pugna are closer to the minimal values of D. megarhinus given by Guérin (1980) but they are also included in the range of morphometrical variability of the remains from Montpellier (see Guérin et al. 1969).

In Italy, D. megarhinus was also reported in other fossiliferous localities of lower significance and usually these records are related to nomenclatural misidentifications with other species. In particular, D. megarhinus was reported at Mulazzano (Parma, Emilia-Romagna) by Simonelli (1897), but the third upper molar recovered in this site can be referred to S. etruscus (Guérin 1980). Guérin (1980) ascribed a mandible from Alta Valle del Serchio (Lucca, Tuscany) to D. megarhinus; however, stratigraphic or chronological information about the site is not available. Isolated teeth probably belonging to the same individual have been collected from a lignite bed at Borgo San Lorenzo (near Florence, Tuscany) and they were ascribed to Rhinoceros cf. leptorhinus (the attribution has to be considered as D. megarhinus) by Leonardi (1947). The teeth are dimensionally smaller than $D$. megarhinus and $S$. jeanvireti and the morphology is similar to that of $S$. etruscus. In agreement with Guérin (1980), the abovementioned remains can be referred to the Etruscan rhino. Moreover, Falconer (1868) and Guérin (1980) ascribed an upper cheek tooth-row from Imola (Bologna, Emilia-Romagna) to D. megarhinus; however, it shows morphological and morphometric characteristics similar to the Etruscan rhino from Capitone (Terni, Umbria) and it was referred to S. etruscus by Pandolfi and Petronio (2011). D. megarhinus was also reported in some Pleistocene sites by Falconer (1868) based on the remains collected from the Tiber River terraces (Rome, Latium). These records were really unfounded and the above-mentioned remains were ascribed to S. hundsheimensis, S. hemitoechus or S. kirchbergensis (see Guérin 1980; Di Stefano et al. 1998; Pandolfi et al. 2013 and references therein). Thus, in Italy, as in Western Europe, D. megarhinus characterized the Early and early Late Pliocene localities only. However, Breda et al. (2010) recently ascribed to Stephanorhinus cf. megarhinus some rhino remains recovered at the early Middle Pleistocene site of Boxgrove (England). These remains consist of teeth (M82482-97) and a fragmentary skull (M82542) (Breda et al. 2010; p. 140-144, Figs 6 and 7). According to the writer, the morphology of the fragmentary skull from Boxgrove partially resembles that of S. etruscus. In particular, in occipital view, the abovementioned skull shows a linear outline of the occipital crest; in dorsal view, the occipital crest has a V-shaped concavity and, in lateral view, is poorly projected over the 
occipital face; the latter is slightly inclined forwards. All these characteristics are clear in the Lectotype of $S$. etruscus (IGF756) from Upper Valdarno. However, the specimen from Boxgrove is dimensionally larger than the Upper Valdarno specimens but is close to the maximal values of $S$. etruscus given by Guérin (1980) except for measures 23 (occipital face height) and 32 (occipital condyles external width). The values of the latter are higher than those reported by Guérin (1980); indeed, the occipital face appears slightly higher in the Boxgrove specimen than in $S$. etruscus. Furthermore, several morphological characteristics of the teeth from Boxgrove can be recognized in some specimens of S. etruscus from Upper Valdarno (e.g., in the maxillae of skull IGF889) and Capitone (MPUR1500), in particular: the isolated protocone of P2/, multiple and complicated crochet in $\mathrm{P} 4 /$ and $\mathrm{P} 3 /$ with small additional spurs, a slight protocone constriction in M1/, the presence of a continuous lingual and mesial cingulum in the premolars, a constriction in the hypocone of $\mathrm{P} 3 /$ and $\mathrm{P} 4 /$, an open mediofossette and a single crochet in M3/. However, in the above-mentioned specimens, the paracone folds appear less marked than in the specimens from Boxgrove. An attribution of these remains to D. megarhinus can be excluded, but new investigations and new remains are needed to identify them.

The rhinoceros remains from Meyrargues (France), previously ascribed to Dicerorhinus mercki, can be referred to D. megarhinus (Bonifay 1961; Guérin 1980). These deposits were usually referred to the Pleistocene; however, according to Bonifay (1961), "L'origine de ces éléments reste assez obscure", but "...ils portent encore des traces du sédiment qui les contenait, un sable calcaire de couleur rouille plus ou moins consolidé en grès." (Bonifay 1961; p. 1, line 16). This calcareous sand can be readily correlated with the ancient depositional series outcropping at Meyrargues, chronologically related to the Pliocene (cf. Ollivier 2011; p. 9).

Finally, von Koenigswald $(1988,1991)$ reported the occurrence of Dicerorhinus cf. megarhinus in the Pleistocene deposits at Gross-Rohrheim (Germany). The morphology of the teeth figured by von Koenigswald (1988, 1991) is quite similar to that of the specimens from Boxgrove. However, the vestibular wall of the premolars from Gross-Rohrheim appears to have less marked paracone folds. The records in Late Pleistocene sites of rhinoceros remains morphologically similar to the Pliocene species are, according to Fortelius et al. (1993), "based on stratigraphic misinterpretation or aberrant individuals improbable, but their significance is unclear".

According to Hürzeler and Engesser (1976) and Guérin (1980), a rhino dimensionally close to D. megarhinus has been recovered in Italy in the faunal assemblage of Baccinello V3 (latest Miocene; Tuscany). Recently, Guérin
(2008) ascribed the remain from Baccinello V3 to Diceros douariensis. This specimen, a fragmentary tibia (NMB sn), is quite different from those of $D$. megarhinus, but new discoveries and a detailed analysis are needed. Furthermore, two upper teeth ascribed to Dicerorhinus cf. megarhinus have been recovered in the latest Miocene deposits of Monticino Quarry (Brisighella, Emilia-Romagna) (De Giuli 1989; Engesser 1989; Rook et al. 1991, 1999). The teeth have a series of common characteristics with $D$. megarhinus. However, due to the records of African genera in Italy during the latest Miocene, a detailed revision of these specimens is needed. Thus, the earliest certain occurrence of D. megarhinus in Italy is at the beginning of the Pliocene in the sites of Val di Pugna. Moreover, in Italy, the records of $D$. megarhinus are limited to the northern area, in particular, in marine deposits of Northern Tuscany (Val di Pugna) and Emilia-Romagna (some localities between Bologna and Piacenza). The last occurrence of the species can be related to the first occurrence of $S$. jeanvireti. The latter rhino has never been recorded together with D. megarhinus, and it is probable that the Italian sites in which $S$. jeanvireti has been reported are younger than the Early Pliocene. Indeed, S. jeanvireti is present during the Late Pliocene (MN16), and, as $D$. megarhinus, it is frequent in the Northern Italian fossiliferous localities (Piedmont, Emilia-Romagna and northern Tuscany). Rare specimens of the small S. etruscus are recorded in the Pliocene sites of Villafranca d'Asti and Montopoli together with the more abundant $S$. jeanvireti. Indeed, the Etruscan rhino is represented only by one talus (IGF1452V) and a fragmentary metatarsal (IGF4688V) in the site of Montopoli (see the description in the previous chapter) and by a distal epiphysis of a humerus (NMB sn) in the site of Villafranca d'Asti. Mazza (1988) considered this record to be too poorly documented and gave scant credit to it. However, S. etruscus is also recorded in Late Pliocene deposits of Castelnuovo di Barardenga Scalo (Cuscani Politi 1963a, 1971) and Città delle Pieve (Fortelius et al. 1993). Moreover, the association S. jeanvireti-S. etruscus is also recorded in other European sites in France, Spain and Romania (Guérin 1980; Mazo 1995; Radulescu and Samson 2001), and it appears to be exclusive of the MN16. At the end of the Late Pliocene, $S$. jeanvireti disappeared, whereas the Etruscan rhino was widespread in Central (Castel San Pietro, Tiberino Basin, L'Aquila Basin) and Southern Italy (Pirro Nord) (Pandolfi and Petronio 2011).

The records of $D$. megarhinus in Italy, and generally in Western Europe, are an important biochronological tool to correlate the European faunal assemblages of the Pliocene. The species appears to be present at first in Southern Europe during the Early Pliocene and later widespread in Asia during the Late Pliocene. These data suggest a 
probable European origin of D. megarhinus, but a careful investigation of the phylogenetic relationships between the Late Miocene and Pliocene taxa is needed to verify this hypothesis.

Acknowledgments I wish to express my gratitude to Dr. Elisabetta Cioppi (Natural History Museum, section Geology and Paleontology, Florence), Dr. Carlo Sarti (Museum of Geology G. Capellini, Bologna), Dr. Riccardo Manni and Sig. Linda Riti (Museum of Paleontology, Sapienza, University of Rome), Dr. Ferruccio Farsi and Prof. Roberto Mazzei (Natural History Museum, Fisiocritici Academy, Siena) and Dr. Loïc Costeur (Natural History Museum Basel) for their help and assistance during the visits to the rhinoceros fossil collections. I also thank two anonymous reviewers for their comments on the manuscript.

\section{References}

Azzaroli, A. (1962). Rinoceronti pliocenici del Valdarno inferiore. Palaeontographia Italica, 57, 11-20.

Azzaroli, A. (1973). Pliocene continentale. In A. Desio (Ed.), Geologia dell'Italia, Utet Torino (pp. 669-673).

Bianucci, G., Mazza, P., Merla, D., Sarti, G., \& Cascella, A. (2001). The early Pliocene mammal assemblage of Val di Pugna (Tuscany, Italy) in the light of calcareous plankton biostratigraphical data and paleoeological observations. Rivista Italiana di Paleontologia e Stratigrafia, 107(3), 425-438.

Bonifay, M. F. (1961). Étude des restes de Rhinocéros de Merck provenant de Meyrargues (Bouches-du-Rhone). Annales de Paléontologie, 47, 77-89.

Brandt, J. F. (1878). Tentamen synopseos rhinocerotidum viventium, et fossilium. Memoires de l'Academie Imperiale des Sciences de St. Petersbourg, 26(5), 1-66.

Breda, M., Collinge, S. E., Parfitt, S. A., \& Lister, A. M. (2010). Metric analysis of ungulate mammals in the early Middle Pleistocene of Britain, in relation to taxonomy and biostratigraphy: I: Rhinocerotidae and Bovidae. Quaternary International, 228(1-2), 136-156.

Capellini, G. (1894). Rinoceronti fossili del Museo di Bologna. Memorie della Regia Accademia delle Scienze dell'Istituto di Bologna, 5(4), 337-349.

Capellini, G. (1913). Resti di mammiferi nelle argille terziarie di Ponzano Magra. Memorie della Regia Accademia delle Scienze dell'Istituto di Bologna, 6(10), 123-128.

Capellini, G. (1920). Rinoceronte fossile di Monte San Pietro. Rendiconti della 9.a Sessione della Regia Accademia delle Scienze dell'Istituto di Bologna, 79-84.

Cerdeño, E. (1989). Spanish Neogene Rhinoceroses. Paleontology, 35, 297-308.

Cerdeño, E. (1995). Cladistic analysis of the family Rhinocerotidae (Perissodactyla). American Museum Novitates, 3143, 1-25.

Coltorti, M., Pieruccini, P., \& Rustioni, M. (2008). The Barga Basin (Tuscany): a record of Plio-Pleistocene mountain building of the Northern Apennines, Italy. Quaternary International, 189, 56-70.

Cortesi, G. (1819). Saggi geologici degli strati di Parma e Piacenza. Piacenza, $X+165$ pp.

Cuscani Politi, P. (1963a). Resti di Rhinoceros (Dicerorhinus) etruscus rinvenuti nel Pliocene del Sense. Atti dell'Accademia delle Scienze di Siena detta de' Fisiocritici, Siena, s. II, 10, 25-57.

Cuscani Politi, P. (1963b). Anche il Rhinoceros megarhinus nel Pliocene dei dintorni di Siena. Atti dell'Accademia delle Scienze di Siena detta de' Fisiocritici, Siena, s II, 10, 125-149.
Cuscani Politi, P. (1971). Altri significativi resti scheletrici del Rhinoceros (Dicerorhinus) etruscus di Castelnuovo Berardenga nei pressi di Siena (Toscana). Atti dell'Accademia delle Scienze di Siena detta de' Fisiocritici, Siena, s XIV, 3, 321-328.

Cuscani Politi, P. (1973). Resti di Rhinoceros (Dicerorhinus) megarhinus rinvenuti nelle sabbie gialle plioceniche di Val Pugna nei pressi di Siena (Toscana). Atti dell'Accademia delle Scienze di Siena detta de' Fisiocritici, Siena, s XIV, 5, 10-17.

Cuscani Politi, P. (1977). Altri resti di Rinoceride rinvenuti nelle formazioni plioceniche di Val Pugna nei pressi di Siena (Toscana). Atti dell'Accademia delle Scienze di Siena detta de' Fisiocritici, Siena, s XIV, 9, 1-13.

Cuvier, G. (1822). Recherches sur les ossemens fossiles de quadrupedes (nouvelle édition, t. 2, 684 p.) Paris: G. Dufour et E. D'Ocagne.

De Christol, J. (1834). Recherches sur les caractères des grandes espèces de Rhinocéros fossiles. Annales des Sciences naturelles, Paris, s., 2(4), 44-112.

De Giuli, C. (1989). The rodents of the Brisighella Latest Miocene fauna. Bollettino della Società Paleontologica Italiana, 28(2-3), $197-212$.

Deng, T., Wang, X., Fortelius, M., Li, Q., Wang, Y., Tseng, Z. J., et al. (2011). Out of Tibet: Pliocene Woolly Rhino suggests high-plateau origin of Ice Age Megaherbivores. Science, 333, $1285-1288$.

Di Stefano, G., Petronio, C., \& Sardella, R. (1998). Biochronology of the Pleistocene mammal faunas from Rome urban area. Il Quaternario, 11(2), 191-199.

Engesser, B. (1989). The Late Tertiary small mammals of the Maremma region (Tuscany, Italy) 2nd part: Muridae and cricetidae (Rodentia, Mammalia). Bollettino della Società Paleontologica Italiana, 28(2-3), 227-252.

Falconer, H. (1868). On the European Pliocene and Post-Pliocene species of the genus Rhinoceros. In C. Murchison, R. Hardwicke (Eds.), Palaeontological Memoirs and Notes of the late Hugh Falconer, (2) Mastodon, Elephant, Rhinoceros, Ossiferous Caves, Primeval Man and His Cotemporaries (pp. 309-403). London.

Fortelius, M., Mazza, P., \& Sala, B. (1993). Stephanorhinus (Mammalia: Rhinocerotidae) of the Western European Pleistocene, with a revision of $S$. etruscus (Falconer, 1868). Palaeontographia Italica, 80, 63-155.

Fukuchi, A., Nakaya, H., Takai, M., \& Ogino, S. (2009). A preliminary report on the Pliocene rhinoceros from Udunga, Transbaikalia, Russia. Asian Palaeoprimatology, Kioto University Primate Research Institute, 5, 61-98.

Geraads, D., \& Spassov, N. (2009). Rhinocerotidae (Mammalia) from the Late Miocene of Bulgaria. Palaeontographica A, 287, 99-122.

Gibbard, P. L., Head, M. J., \& Walker, M. J. C. (2010). Formal ratification of the Quaternary System/Period and the Pleistocene Series/Epoch with a base at 2.58 Ma. Journal of Quaternary Science, 25(2), 96-102.

Guérin, C. (1972). Une nouvelle espèce de Rhinocéros (Mammalia, Perissodactyla) à Vialette (Haute-Loire, France) et dans d'autres gisements du Villafranchien Inférieur Européen: Dicerorhinus jeanvireti n. sp. Documents des Laboratoires de Géologie de la Facultè des Sciences de Lyon, 49, 53-161.

Guérin, C. (1980). Les rhinoceros (Mammalia, Perissodactyla) du Miocene terminal au Pleistocene superieur en Europe occidentale; comparaison avec les especes actuelles. Documents du Laboratoire de Geologie de la Faculte des Sciences de Lyon, 79, 3-1183.

Guérin, C. (1982). Les Rhinocerotidae (Mammalia, Perissodactyla) $\mathrm{du}$ miocene terminal au pleistocene superieur d'Europe occidentale compares aux especes actuelles: tendences evolutives et relations phylogenetiques. Geobios, 15(4), 599-605. 
Guérin, C. (2004). Les rhinoceros (Mammalia, Perissodactyla) du gisement villafranchien moyen de Saint-Vallier (Drome). Geobios, 37, 259-278.

Guérin, C. (2008). The Miocene Rhinocerotidae (Mammalia) of the Northern Sperrgebiet, Namibia. Memoir of the Geological Survey of Namibia, 20, 331-341.

Guérin, C., Ballesio, R., \& Meon-Vilain, H. (1969). Le Dicerorhinus megarhinus (Mammalia, Rhinocerotidae) du Pliocene de SaintLaurent-des-Arbres (Gard). Documents des Laboratories de Geologie de la Faculte des Sciences de Lyon, Notes et Memoires, $31,55-145$.

Guérin, C., \& Santafé-Llopis, J. V. (1978). Dicerorhinus miguelcrusafonti nov sp, une nouvelle espece de rhinoceros (Mammalia, Perissodactyla) du gisement pliocene superieur de Layna (Soria, Espagne) et de la formation pliocene de Perpignan (Pyrenees-Orientales, France). Geobios, 11(4), 457-491.

Guérin, C., \& Sen, S. (1998). Rhinocerotidae. In Sen S. (Ed.), Le gisement de vertébrés pliocènes de Çalta, Ankara, Turquie. Geodiversitas, 20(3), 397-407.

Heissig, K. (1999). Family Rhinocerotidae. In G. E. Rössner \& K. Heissig (Eds), The Miocene Land Mammals of Europe (pp. 175-188). Munich: Pfeil.

Hürzeler, J., \& Engesser, B. (1976). Les faunes de mammifères néogènes du bassin de Baccinello (Grosseto, Italie). Comptes Rendus de l'Académie des Sciences de Paris, 293, 333-336.

Kotsakis, T. (1986). Elementi di paleobiogeografia dei mammiferi terziari dell'Italia. Hystrix, 1, 25-68.

Kotsakis, T., Barisone, G., \& Rook, L. (1997). Mammalian biochronology in an insular domain: the Italian Tertiary faunas. Mémoires et Travaux de l'École Pratiques des Hautes Etudes, Institut de Montpellier, 21, 431-441.

Lacombat, F. (2005). Les rhinocéros fossiles des sites préhistoriques de l'Europe méditerranéenne et du Massif central. Paléontologie et implications biochronologiques. BAR International Series, $1419,1-175$

Lacombat, F., \& Mörs, T. (2008). The northernmost occurrence of the rare Late Pliocene rhinoceros Stephanorhinus jeanvireti (Mammalia, Perissodactyla). Neues Jahrbuch für Geologie und Paläontologie Abhandlungen, 249(2), 157-165.

Leonardi, P. (1947). Resti fossili inediti di rinoceronti conservati nelle collezioni dell'Istituto Geologico dell'Università di Padova. Memorie dell'Istituto di Geologia dell'Università di Padova, 15, $1-30$.

Mazo, A. V. (1995). Stephanorhinus etruscus (Perissodactyla, Mammalia) en el Villafranquiense inferior de Las Higueruelas, Alcolea de Calatrava (Ciudad Real). Estudios Geologicos, 51, 285-290.

Mazza, P. (1988). The Tuscan Early Pleistocene rhinoceros Dicerorhinus etruscus. Palaeontographia Italica, 75, 1-87.

Ollivier, V. (2011). Les formations travertineuses et détritiques pléistocènes à postglaciaires du piémont sud du grand Luberon.
In V. Ollivier, J. -L. Guendon (Eds.), Excursion de l'Association Française pour l'Etude du Quaternaire (AFEQ) 21 au 23 juin 2011: Paysages, travertins et paléoenvironnements quaternaires entre Provence et Alpes occidentales: livret-guide (pp. 14-33). Aix-en-Provence: UMR 6636 "LAMPEA".

Pandolfi, L., Gaeta, M., \& Petronio, C. (2013). The skull of Stephanorhinus hemitoechus (Mammalia, Rhinocerotidae) from the Middle Pleistocene of Campagna Romana (Rome, Central Italy): biochronological and paleobiogeographic implications. Bullettin of Geoscience, 88(1), 51-62.

Pandolfi, L., \& Petronio, C. (2011). Stephanorhinus etruscus (Falconer, 1868) from Pirro Nord (Apricena, Foggia, Southern Italy) with notes on the late Early Pleistocene rhinoceroses of Italy. Rivista Italiana di Paleontologia e Stratigrafia, 117(1), 173-187.

Radulescu, C., \& Samson, P. M. (2001). Biochronology and evolution of the early Pliocene to the early Pleistocene mammalian faunas of Romania. Bollettino della Società Paleontologica Italiana, 40(2), 285-291.

Rook, L., Abbazzi, L., \& Engesser, B. (1999). An overview on the Italian Miocene Land Mammal fauna. In J. Augustì, L. Rook \& P. Andrew (Eds.), The evolution of Neogene terrestrial ecosystems in Europe (Vol., pp. 191-204)

Rook, L., Ficcarelli, G., \& Torre, D. (1991). Messianian carnivores from Italy. Bollettino della Società Paleontologica Italiana, 30(17), 7-22.

Sacco, F. (1895). Le rhinocéros de Dusino (Rhinoceros etruscus Falc., var. astensis Sacc.). Archives du Muséum d'Histoire naturelle de Lyon, 6, 1-31.

Sacco, F. (1906). Resti fossili di Rinoceronti dell'Astigiana. Memorie della Regia Accademia delle Scienze di Torino, s., 2(56), $105-116$.

Simonelli, V. (1897). I Rinoceronti fossili del museo di Parma. Palaeontographia Italica, 3, 89-136.

Simonelli, V. (1919). Spigolature Paleontologiche (Mem. del Prof. Vittorio Simonelli letta nella Sess. del 25 maggio 1919). Memorie della Regia Accademia delle Scienze dell'Istituto di Bologna (classe di Scienze Fisiche), s VII, 6, 182-185.

Tong, H. W. (2012). Evolution of the non-Coelodonta dicerorhine lineage in China. Comptes Rendus Palevol, 11(8), 555-562.

Ugolini, R. (1918). Il Rhinoceros etruscus Falconer del Pliocene di Barga. Palaeontographia Italica, 24, 121-128.

von Koenigswald, W. (1988). Paläoklimatische Aussage letztininterglazialer Säugethiere aus der nördlichen Oberrheinebene. In W. von Koenigswald (Ed.), Zur Paläoklimatologie des letzten Interglazials im Nordteil der Oberrheinebene, Gustav Fischer (pp. 205-214). Stuttgart.

von Koenigswald, W. (1991). Exoten in der Großsäuger-Fauna des letzten Interglazials von Mitteleuropa. Eiszeitalter und Gegenwart, Hannover, 41, 70-84. 